University of Nebraska - Lincoln

DigitalCommons@University of Nebraska - Lincoln

June 2008

\title{
Determinants of Income Growth in Metropolitan and Nonmetropolitan Labor Markets
}

\author{
George W. Hammond \\ West Virginia University, ghammond@eller.arizona.edu \\ Eric C. Thompson \\ University of Nebraska-Lincoln, ethompson2@unl.edu
}

Follow this and additional works at: https://digitalcommons.unl.edu/econfacpub

Part of the Economics Commons

Hammond, George W. and Thompson, Eric C., "Determinants of Income Growth in Metropolitan and Nonmetropolitan Labor Markets" (2008). Economics Department Faculty Publications. 25.

https://digitalcommons.unl.edu/econfacpub/25

This Article is brought to you for free and open access by the Economics Department at DigitalCommons@University of Nebraska - Lincoln. It has been accepted for inclusion in Economics Department Faculty Publications by an authorized administrator of DigitalCommons@University of Nebraska - Lincoln. 
Published in American Journal of Agricultural Economics 90:3 (2008), pp. 783-793; doi 10.1111/j.1467-8276.2008.01135.x

Copyright (C) 2008 American Agricultural Economics Association; published by John Wiley\& Sons, Inc.

http://www3.interscience.wiley.com/journal/118482046/home Used by permission.

GWH received partial funding support for this research from the Kennedy-Vanscoy Fund for

Faculty Development in the College of Business and Economics, West Virginia University.

The authors thank the editor and two anonymous referees for $A J A E$ for constructive comments.

Submitted December 2006; accepted November 2007; published online June 28, 2008.

\title{
Determinants of Income Growth in Metropolitan and Nonmetropolitan Labor Markets
}

\author{
George W. Hammond* and Eric C. Thompson** \\ * Associate Director, BBER and Associate Professor of Economics, Department of Economics \\ and Bureau of Business and Economic Research, West Virginia University \\ ** Director, BBR and Associate Professor of Economics, Department of Economics and Bureau \\ of Business Research, University of Nebraska-Lincoln.
}

\begin{abstract}
This article analyzes determinants of growth across labor markets in the United States, using a production function approach based on four inputs: labor, manufacturing investment, human capital investment, and public capital investment. We find little role for public capital investment in growth, but that manufacturing investment spurred growth in nonmetropolitan areas, in contrast to metropolitan areas. We also find that human capital investment mattered more for metropolitan areas than for nonmetropolitan areas. Further, the presence of more colleges and universities, more household amenities, and lower tax rates are all found to have encouraged human capital accumulation in U.S. labor markets.
\end{abstract}

Keywords: constant elasticity of substitution, income growth, metropolitan, nonmetropolitan, Solow growth model

Persistent and large differences in the level of income between countries and within countries have attracted much attention from economists. For example, using data for U.S. states for 1999, per capita personal income in Connecticut was $91.2 \%$ higher than in Mississippi. Income differences are even larger as we disaggregate states into smaller labor market areas. Indeed, using one definition of substate labor markets (commuting zones for the continental United States (Tolbert and Sizer [1996]), we find that the income difference between the highest income area and the lowest was 279\% in 1969 and 335\% in 1999. ${ }^{1}$

Many of the lowest income labor market areas are nonmetropolitan, yet a large share of the research on regional growth has focused solely on cities and metropolitan statistical areas. This research has used a wide variety of explanatory variables, including human cap-

${ }^{1}$ In 1969, the commuting zone region with the highest per capita personal income was Nantucket County, Massachusetts $(\$ 5,111)$. The commuting zone region with the lowest income was Maverick County, Texas $(\$ 1,349)$. In 1999, the region with the highest income was the Teton zone (including Teton counties in Idaho and Wyoming) with $\$ 47,050$. The lowest income region was Maverick County, Texas, with $\$ 10,826$. ital, industry mix, amenities, race, and geography, as well as inputs into the production process, like manufacturing and public capital investment. Human capital investment, measured by education attainment, is often found to be highly correlated with strong metropolitan growth, for instance in Drennan (2005), Glaeser and Saiz (2004), Simon (1998), Glaeser, Scheinkman, and Shleifer (1995), and Crihfield and Panggabean (1995).

Studies focused on metropolitan areas may or may not generate findings that are relevant for U.S. nonmetropolitan areas, a significant omission given that $17 \%$ of U.S. population in 2000, which amounts to 49 million residents, live in nonmetropolitan counties. Further, studies that focus exclusively on metropolitan areas or cities may suffer from sample selection bias. To remedy this, Hammond and Thompson (2006), Hammond (2006), Hammond (2004), Henry, Barkley, and Li (2004), Huang, Orazem, and Wohlgemuth (2002), Rupasingha, Goetz, and Freshwater (2002), Beeson, DeJong, and Troesken (2001), Nissan and Carter (1999), and Carlino and Mills (1987) investigated convergence and growth issues us- 
ing data encompassing both metropolitan and nonmetropolitan areas. However, most of these past efforts have not focused on pinning down differences in growth determinants across metropolitan and nonmetropolitan areas in the lower forty-eight U.S. states.

A more formal structural approach to growth determinants across metropolitan and nonmetropolitan areas encompassing the lower forty-eight U.S. states would provide the opportunity to investigate whether heterogeneity occurs due to differences in investment rates across labor markets or rather due to differences in structural parameters reflecting differences in technology. This may aid policy makers at the state and local level as they allocate scarce resources to enhance economic development.

In this article we specify a Solow (1956) growth model with four inputs: labor, public infrastructure, private manufacturing plant and equipment, and human capital. We employ a constant-elasticity-of-substitution (CES) production function, in contrast to previous studies using U.S. regional data, which have assumed a Cobb-Douglas (CD) production function. The added flexibility of the CES production function allows us to investigate the role of the elasticity of substitution in growth. As Klump and Preissler (2000) show analytically, and Masanjala and Papageorgiou (2004), Duffy and Papageorgiou (2000) show empirically using an international data set, the elasticity of substitution can play in important role in the growth process.

We prefer the production function approach because our goal is to understand the relative importance of human, manufacturing, and public capital development in the regional growth process. We are interested in these inputs because the state and local policy debate frequently revolves around them. With respect to manufacturing capital investment, we would prefer a broader measure that reflected capital expenditures across all industries, but none exists at the substate regional level. Therefore, we pursue our analysis with manufacturing data, noting that the manufacturing industry is of interest to policy makers who design economic development policies. We also contribute to the literature by examining an important type of parameter heterogeneity: differences across metropolitan and nonmetropolitan areas. Finally, we treat all investment rates as endogenous, which as Crihfield and Panggabean (1995) point out, is an important consideration.
Using data for 722 labor market areas in the continental United States, we find distinct structural differences across metropolitan and nonmetropolitan areas. Our results suggest that human capital is an important driver of income growth for nonmetropolitan areas, as well as for metropolitan areas. However, we note that human capital investment has a larger impact on growth in metropolitan areas than in nonmetropolitan areas. We also find that private capital investment in manufacturing has a positive and significant impact on per capita personal income growth in nonmetropolitan areas, but no significant impact on growth in metropolitan areas, which is consistent with the more severe decline in manufacturing jobs in metropolitan areas during the period. Further, consistent with the literature, public capital investment has no significant impact on per capita income growth for metropolitan and nonmetropolitan areas. Finally, we find only mixed support for the CES production function and the role of the elasticity of substitution in contributing to regional growth during the period.

\section{Literature and Theoretical Framework}

Issues of regional economic growth and convergence have generated a large and growing body of research, but much of this activity has focused on data sets at the state or even multistate region level. ${ }^{2}$ However, these regional definitions may not make much economic sense, because states are made up of diverse collections of metropolitan and nonmetropolitan areas and, in addition, it is common for local labor markets to spill across state lines. In order to avoid the distortions inherent in state-level data sets, many studies have examined growth and related issues at the metropolitan and city level.

Lucas (1988) argues that cities are the preferred unit of analysis when human capital (and associated externalities) may be an important component of the growth process. For instance, Drennan (2005), Glaeser and Saiz (2004), Simon and Nardinelli (2002), Simon (1998), Glaeser, Scheinkman, and Shleifer (1995), Crihfield and Panggabean (1995) and Rauch (1993) examine determinants of growth for metropolitan areas (and cities) and find that human

\footnotetext{
2 See for example, Barro and Sala-i-Martin (1992), using cross-section regression, Carlino and Mills (1993, 1996), using time-series regression, and Quah (1996), using distribution dynamics methods to investigate convergence concepts using state data.
} 
capital has a powerful impact on economic performance, as measured by population, employment, and income growth, as well as on productivity. These studies also examine a variety of influences on metropolitan growth, including industry mix, amenities, race, and geography, as well as manufacturing and public capital investment.

However, a focus on metropolitan areas and cities may yield results that are biased toward convergence, since, by design, the data exclude nonmetropolitan areas. As noted by Beeson, DeJong, and Troesken (2001) the focus on cities and metropolitan areas may lead to the sort of selection bias noted by DeLong (1988) in his analysis of Baumol's (1986) convergence results for OECD countries. A more general investigation of convergence and growth should consider all labor markets, not just a subset, even if that subset accounts for a large share of the population.

In addition, the focus on metropolitan areas ignores possible parameter heterogeneity across U.S. labor markets. It will naturally tend to focus policy prescriptions on factors that affect metropolitan growth. This advice is likely to be applied by policy makers to all labor markets, metropolitan or not, even though this literature does not directly present evidence on relevant correlations for nonmetropolitan areas.

To address these issues, the literature has investigated convergence and growth in more diverse groups of substate economic areas, including both metropolitan and nonmetropolitan areas. Hammond and Thompson (2006), Hammond (2006), Hammond (2004), Henry, Barkley, and Li (2004), Huang, Orazem, and Wohlgemuth (2002), Rupasingha, Goetz, and Freshwater (2002), Beeson, DeJong, and Troesken (2001), Nissan and Carter (1999), and Carlino and Mills (1987) explore the issue of growth in metropolitan and nonmetropolitan areas, using a variety of empirical approaches including distribution dynamics, time-series methods, spatial distribution dynamics, cross-section regressions, and trends in cross-section standard deviations.

However, to date, there has been no comprehensive effort to examine how the determinants of growth differ across all of the metropolitan and nonmetropolitan areas in the United States. We fill this gap by building a county-level data base for the lower forty-eight U.S. states and then aggregating our county data into metropolitan and nonmetropolitan labor markets based on Economic Research Service (ERS) commuting zones. Further, we focus on a formal production pro- cess with four inputs: labor, private physical capital, public infrastructure capital, and human capital. Our interest is drawn to these inputs because the state and local policy debate revolves around them.

In order to investigate these issues, we start with a model that describes a one-sector economy with a CES production function. We include four inputs: labor, private physical capital, public infrastructure capital, and human capital. By employing a CES production function, we depart from earlier work by allowing the elasticity of substitution to differ from one. CES production functions are becoming increasingly popular in the empirical literature on international growth and convergence (Masanjala and $\mathrm{Pa}-$ pageorgiou (2004), Duffy and Papageorgiou (2000)). They are attractive in this context because they allow us to investigate the role of the elasticity of substitution in the growth process and because they encompass the CD specification.

Following Masanjala and Papageorgiou (2004) we specify the following CES production function with labor augmenting technological progress:

$$
\begin{aligned}
\mathrm{Y}= & {\left[\alpha K^{\rho}+\beta H^{\rho}+\gamma Z^{\rho}\right.} \\
& \left.+(1-\alpha-\beta-\gamma)(A L)^{\rho}\right]^{\frac{1}{\rho}}
\end{aligned}
$$

where $\mathrm{A}$ is exogenous technology, which grows at rate $\mathrm{g}, \mathrm{Y}$ is real output, $\mathrm{K}$ is the private physical capital stock, $\mathrm{Z}$ is the stock of public capital, $\mathrm{H}$ is the stock of human capital, and L is the labor force, which grows at rate $\mathrm{n}$ (we suppress time subscripts). We expand on the work of Masanjala and Papageorgiou (2004) through our inclusion of public capital stock as an input. The parameters $\alpha, \beta, \gamma$ are distribution parameters. The elasticity of substitution $(\sigma \geq 0)$ is defined as $1 /(1-\rho)$.

In this four factor case, we focus on the Allen Partial Elasticity of Substitution (Allen, 1938, pp. 503$509)$, assuming it to be constant across input pairs: $\sigma_{\mathrm{ij}}$ $=\sigma$ for $i, j=(K, H, Z, A L)$ and $i \neq j$. If $\rho=0(\sigma=1)$, the CES production function reduces to the CD case. On the other end of the spectrum, if $\rho=1(\sigma=\infty)$, we have the perfect substitution case. If $\rho=-\infty(\sigma=0)$ we have the fixed proportions case.

We use the production function and standard formulations for the accumulation of human, public, and private capital to solve for steady-state output. In order to facilitate estimation, we compute a linearized version of the steady-state solution via a second-order Taylor series expansion around $\rho=0$, as shown in Hammond and Thompson (2008). 
Since regional economies may not be at their steady states at all times, we follow Crihfield and Panggabean (1995) and account for partial adjustment to the steady state using

$$
\begin{aligned}
& \ln \left(\frac{Y}{L}\right)_{t}-\ln \left(\frac{Y}{L}\right)_{0} \\
& \quad=(1-\pi)\left[\ln \left(\frac{Y}{L}\right)_{t}^{*}-\ln \left(\frac{Y}{L}\right)_{0}\right]
\end{aligned}
$$

where the starred term indicates the steady state.

Our final solution, expressed in the typical growth regression form is

$$
\begin{aligned}
& \ln \left(\frac{Y}{L}\right)_{t}-\ln \left(\frac{Y}{L}\right)_{0} \\
& =(1-\pi) \ln A(0)+(1-\pi) g t \\
& -\frac{(1-\pi)(\alpha+\beta+\gamma)}{(1-\alpha-\beta-\gamma)} \ln (\delta+n+g) \\
& +\frac{(1-\pi) \alpha}{(1-\alpha-\beta-\gamma)} \ln \left(S_{k}\right) \\
& +\frac{(1-\pi) \beta}{(1-\alpha-\beta-\gamma)} \ln \left(S_{h}\right) \\
& +\frac{(1-\pi) \gamma}{(1-\alpha-\beta-\gamma)} \ln (S z) \\
& +\frac{\rho}{2} \frac{(1-\pi)}{(1-\alpha-\beta-\gamma)^{2}} \\
& \times\left[\begin{array}{c}
\alpha\left(\ln \left(\frac{S_{k}}{\delta+n+g}\right)\right)^{2}+\beta\left(\ln \left(\frac{S_{h}}{\delta+n+g}\right)\right)^{2} \\
+\gamma\left(\ln \left(\frac{S_{z}}{\delta+n+g}\right)\right)^{2} \\
-\alpha \beta\left(\ln \left(\frac{S_{k}}{S_{h}}\right)\right)^{2}-\beta \gamma\left(\ln \left(\frac{S_{h}}{S_{z}}\right)\right)^{2} \\
-\alpha \gamma\left(\ln \left(\frac{S_{k}}{S_{z}}\right)\right)^{2}
\end{array}\right] \\
& -(1-\pi) \ln \left(\frac{Y}{L}\right)_{0}
\end{aligned}
$$

where $S_{k^{\prime}}, S_{h^{\prime}}$ and $S_{z}$ are shares of output invested in each form of capital and we make the standard assumption that all forms of capital depreciate at the same rate $(\delta)$. Note that if $\rho=0(\sigma=1)$ our formulation reverts to the CD solution. This will facilitate a test for misspecification in research that has assumed a $\mathrm{CD}$ production function.

We estimate equation (1) in the following section, after converting to annual rates. It allows us to test for the relative influence of each form of investment on growth and to identify parameter heterogeneity across metropolitan and nonmetropolitan areas.

\section{Empirical Results}

We estimate the model using data from 722 local labor market areas (LMAs) in the continental United States. These mutually exclusive and exhaustive local labor markets were developed by the U.S. Department of Agriculture's Economic Research Service (ERS) to capture commuting zones in nonmetropolitan as well as metropolitan areas. These ERS commuting zones are aggregations of counties. Of the 722 LMAs, 256 are metropolitan and 466 are nonmetropolitan. Metropolitan areas include one or more metropolitan statistical areas (MSAs) and nonmetropolitan areas are those which do not contain any counties included in an MSA (Tolbert and Sizer (1996)). These labor market areas, which county-to-county commuting data from the 1990 Census reveal to be integrated labor markets, are an appropriate aggregation of counties for the study of variables influenced by the labor market, such as per capita personal income growth. We also prefer aggregating county data to the LMA level because it reduces the influence of spatial spillovers on our results, particularly when compared to county data.

Detailed descriptions and sources for all investment and growth variables are provided in Hammond and Thompson (2008). Table 1 contains summary statistics and brief descriptions of the data. In most cases we acquire county-level data and aggregate to labor market areas. We use real per capita personal income as our measure of income growth. This is a broad measure of income, including earnings from work, asset income, and transfer receipts. The average annual growth rate of real per capita income (deflated using the U.S. CPI-U for all items, all cities) for all areas was $1.62 \%$ per year during the $1969-99$ period. ${ }^{3}$ Growth was faster in metropolitan areas (at $1.67 \%$ per year) than in nonmetropolitan areas $(1.59 \%)$. Real per capita personal income was significantly higher in metropolitan areas (\$15,300 in 1982-84 dollars on average in 1999) than in nonmetropolitan areas $(\$ 12,715)$.

\footnotetext{
${ }^{3}$ It is common in the literature on convergence and growth to abstract from cost-of-living differences, because these are notoriously difficult to measure. However, as Deller, Sheilds, and Tomberlin (1996), among others, argue, cost-of-living differences may influence the results.
} 
Table 1. Summary Statistics.

\begin{tabular}{|c|c|c|c|c|c|c|}
\hline \multirow[b]{2}{*}{ Variables } & \multicolumn{2}{|c|}{ All LMAs } & \multicolumn{2}{|c|}{ Metro LMAs } & \multicolumn{2}{|c|}{ Nonmetro LMAs } \\
\hline & Mean & Std. Dev. & Mean $\subseteq$ & Std. Dev. & Mean & Std. Dev. \\
\hline \multicolumn{7}{|l|}{ Growth Model } \\
\hline $\begin{array}{l}\text { Average annual growth in real per } \\
\text { capita income from } 1969 \text { to } 1999 \text {, } \\
\ln (Y / L)_{1999}-\ln (Y / L)_{1969}\end{array}$ & $1.62 \%$ & $0.49 \%$ & $1.67 \%$ & $0.37 \%$ & $1.59 \%$ & $0.55 \%$ \\
\hline $\begin{array}{l}\text { Average annual private sector } \\
\text { investment in manufacturing as } \\
\text { a share of income in LMA, } S_{k}\end{array}$ & $2.50 \%$ & $2.01 \%$ & $3.15 \%$ & $2.33 \%$ & $2.14 \%$ & $1.77 \%$ \\
\hline $\begin{array}{l}\text { Average annual local public capital } \\
\text { outlay as a share of income in LMA, } S_{z}\end{array}$ & $1.37 \%$ & $2.81 \%$ & $1.31 \%$ & $0.37 \%$ & $1.41 \%$ & $0.64 \%$ \\
\hline $\begin{array}{l}\text { Average annual change in years } \\
\text { of schooling, } S_{h}\end{array}$ & 0.044 & 0.0077 & 0.0449 & 0.0076 & 0.0434 & 0.0076 \\
\hline $\begin{array}{l}\text { Average annual population growth } \\
\text { plus average annual manufacturing } \\
\text { depreciation plus technology growth, } \\
(\delta+g+n)\end{array}$ & $4.60 \%$ & $1.33 \%$ & $5.22 \%$ & $1.05 \%$ & $4.27 \%$ & $1.34 \%$ \\
\hline $\begin{array}{l}\text { Real per capita personal income } \\
\text { in LMA in } 1969(\$ 1,000),(Y / L)_{1969}\end{array}$ & $\$ 8.44$ & $\$ 1.71$ & $\$ 9.31$ & $\$ 1.58$ & $\$ 7.97$ & $\$ 1.58$ \\
\hline \multicolumn{7}{|l|}{ Factor Market Model } \\
\hline $\begin{array}{l}\text { Average annual taxes as a share of } \\
\text { income in LMA, Tax }\end{array}$ & $10.06 \%$ & $1.39 \%$ & $9.75 \%$ & $1.20 \%$ & $10.24 \%$ & $1.93 \%$ \\
\hline $\begin{array}{l}\text { Average price of electricity per BTU } \\
\text { for industrial customers. Elecpr }\end{array}$ & $\$ 10.42$ & $\$ 2.08$ & $\$ 10.99$ & $\$ 2.29$ & $\$ 10.11$ & $\$ 1.88$ \\
\hline $\begin{array}{l}\text { Average price of natural gas per BTU } \\
\text { for industrial customers, NGaspr }\end{array}$ & $\$ 2.63$ & $\$ 0.43$ & $\$ 2.72$ & $\$ 0.47$ & $\$ 2.58$ & $\$ 0.39$ \\
\hline Share of unionized workforce, Union & $19.85 \%$ & $7.57 \%$ & $20.75 \%$ & $8.37 \%$ & $19.34 \%$ & $7.06 \%$ \\
\hline Topographic scale, Topog & 9.29 & 6.12 & 8.63 & 6.11 & 9.66 & 6.10 \\
\hline Avg. ann. death rate in LMA, Deathrt & $0.98 \%$ & $0.21 \%$ & $0.88 \%$ & $0.14 \%$ & $1.04 \%$ & $0.22 \%$ \\
\hline $\begin{array}{l}\text { Four-year colleges and universities } \\
\text { per 1,000 persons, Univpc }\end{array}$ & 0.0081 & 0.0114 & 0.0083 & 0.0055 & 0.0079 & 0.0137 \\
\hline $\begin{array}{l}\text { Mean January temperature in LMA, } \\
\text { Tempjan }\end{array}$ & 31.77 & 12.61 & 35.66 & 12.49 & 29.63 & 12.17 \\
\hline $\begin{array}{l}\text { Mean July temperature in LMA, } \\
\text { Tempjul }\end{array}$ & 75.37 & 5.66 & 76.24 & 5.23 & 74.9 & 5.84 \\
\hline Pct. surface covered by water, Pctwater & 4.5 & 9.89 & 6.4 & 9.45 & 3.46 & 9.98 \\
\hline
\end{tabular}

We use data on new capital expenditures in the manufacturing sector as our measure of private capital investment $\left(\mathrm{S}_{\mathrm{k}}\right)$. We would prefer a broader measure that reflected capital expenditures across all industries, but none exists at the substate level. New manufacturing capital expenditures relative to area in- come average $2.50 \%$ across LMAs during the period, with investment rates in metropolitan areas (at 3.15\%) well above rates in nonmetropolitan areas $(2.14 \%)$.

Public capital outlays $\left(S_{z}\right)$, again relative to area income, average $1.37 \%$ for all LMAs, with generally smaller rates of investment for metropolitan ar- 
eas than for nonmetropolitan areas. This measure of local government spending reflects local spending for infrastructure development (transportation, water, and sewer), as well as government structures. For both manufacturing and public sector investment, our measures are the same concepts employed in Crihfield and Panggabean (1995).

Finally, we find differences in human capital investment $\left(\mathrm{S}_{\mathrm{h}}\right)$ between metropolitan and nonmetropolitan areas during the period. Using decennial Census data, we estimated the average annual increase in years of schooling per worker age twentyfive years or older. Average years of schooling grew by 0.044 annually for all LMAs from 1970 to 2000, with slightly faster growth (0.045) in metropolitan areas than in nonmetropolitan areas (0.043). This measure focuses on the change in the stock of human capital, which better reflects the investment concept, in contrast to the average level of educational attainment used in Crihfield and Panggabean (1995) and the beginning-period educational attainment (or median years of schooling) used in Glaeser, Scheinkman, and Shleifer (1995). The coverage of our measure is similar to Crihfield and Panggabean (1995) and Glaeser, Scheinkman, and Shleifer (1995) in the sense that it reflects both high school and college level attainment. Human capital measures employed in Hammond and Thompson (2006), and Hammond (2006), and Rupasingha, Goetz, and Freshwater (2002) focused on college or better levels of educational attainment. Henry, Barkley, and Li (2004) use the share of the population with at least some college as their indicator of human capital investment.

\section{Factor Market Model}

As in Crihfield and Panggabean (1995), we consider the potential endogeneity of the factors of production in the Solow growth model. This possible endogeneity comes about because we consider small open economies, with free flows of capital and labor among labor markets. Thus, in contrast to assumptions driving some international studies, investment rates and population growth will influence, and be influenced by, income growth. Since failure to deal with this endogeneity problem will result in biased and inconsistent parameter estimates from our growth model, we adopt a two-stage approach in which investment rates (and population growth) are modeled in the first stage and then predicted values are utilized in estimating the growth model.

Descriptions and sources for variables used in reduced form equations for each of the factors of production can be found in Hammond and Thompson (2008). Summary statistics are available in Table 1. We include annual taxes as a share of income (Tax), state average industrial electricity prices (Elecpr), and state industrial natural gas prices (NGaspr) along the lines of Crihfield and Panggabean (1995), as well as the state level of unionization (Union). These cost variables are expected to reduce private sector factor growth (private physical and human capital investment, and population growth), but in the case of taxation encourage growth in public sector investment.

We also included a number of other variables expected to influence the rate of investment and population growth in labor market areas. The presence of more four-year colleges and universities per person (Univpc) is expected to encourage growth in education attainment, along the lines of Beeson, DeJong, and Troesken (2001) and Glaeser and Saiz (2004). We include several amenity variables, which have been shown to matter in this context, for example by Deller et al. (2001) and Kim, Marcouiller, and Deller (2005). We include in the factor market models the mean temperatures for January (Tempjan) and July (Tempjul) to reflect the local climate and a measure of the percent of the area covered by water (Pctwater) to reflect proximity to the coast, lakes, and/or rivers. As noted by many others, we expect higher January temperatures, lower July temperatures, and greater access to coasts, lakes, and/or rivers to encourage faster population growth. We also include an indicator of topography (Topog) developed in McGranahan (1999). This topography scale (1 through 21 ) runs from 1 (plains) to 21 (high mountains). We expect this measure to reflect higher costs for building public and private physical capital in rougher terrain and to reflect recreation amenities that encourage population growth.

Finally, we expect the death rate (Deathrt) to influence the natural rate of population growth, as well as the level of public sector physical capital investment, and we include a set of state dummy variables in each factor market regression.

We use these variables to estimate reduced form equations for the three types of investment and population growth. Table 2 shows the results of these factor market model regressions. Results overall indi- 
Table 2. Results of Factor Market Models.

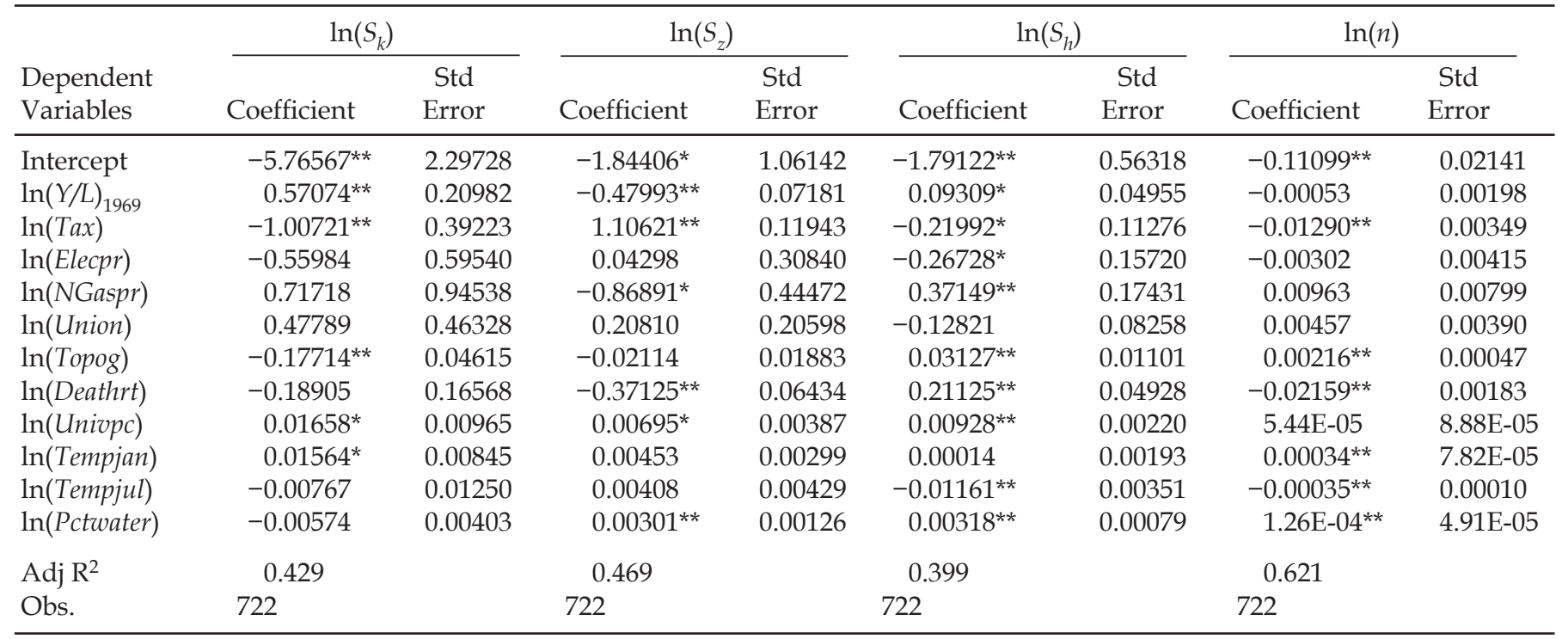

Note: A single asterisk $\left({ }^{*}\right)$ denotes statistically significant at $10 \%$ level. Double asterisks $\left({ }^{* *}\right)$ denote statistically significant at $5 \%$ level. Regressions are corrected for heteroskedasticity using White (1980).

cate that higher taxes and the presence of business dis-amenities like a rough terrain (a higher value for the topography variable) discourage manufacturing investment. Taxes on the other hand encourage public physical capital investment. Further, a rough terrain does not discourage public capital investment, indicating that the public sector is less sensitive to investment costs than the private sector. A higher death rate, characteristic of an older population, also discouraged public capital investment, perhaps due to a shorter time horizon to benefit from these investments.

We find that higher taxes discourage population growth, but household amenities such as rougher terrain, mild temperatures, and proximity to coasts, lakes, and/or rivers encourage it. A higher death rate discourages population increase, as would be expected. The presence of more colleges and universities per capita encourages increases in human capital investment. Amenities also encourage growth in human capital, presumably by encouraging net immigration. Younger workers are both more likely to migrate and have higher education levels.

\section{Solow Growth Model with a CES Production Function}

We first implement Hausman tests to provide evidence on the exogeneity of our investment rates and population growth. This test compares parameter estimates of equation 1 computed using our original investment rates and population growth to parameter estimates computed using the predicted rates from our factor market models. Significant differences between these parameter estimates suggest that endogeneity is a problem. We reject the exogeneity of public capital (at the 1\% significance level), human capital (at $1 \%$ ), and population growth (at $10 \%$ ), though not private manufacturing investment. The results of these tests suggest that the two-stage approach will improve the estimation compared to ordinary least squares by eliminating a source of correlation between these right-hand side variables and the error term. ${ }^{4}$

We next use data for all LMAs to estimate restricted versions of equation (1), making use of predicted values derived from our first stage regressions. Table 3 contains the restricted estimations, obtained via nonlinear least squares. The coefficient standard errors are corrected to ensure consistency. The restricted estimates suggest that manufacturing and human capital investments are significantly and positively correlated with income growth. Results for public capital investment suggest a significant negative correlation, which is consistent with the results of Crihfield and Panggabean (1995) and Glaeser, Scheinkman, and

\footnotetext{
${ }^{4}$ Our overall results are similar if we use starting period values. We prefer the two-stage approach because it provides information regarding influences on investment rates.
} 
Table 3. Results for CES and CD Models: Restricted Estimation of Equation 1 Dependent Variable: $\ln (Y / L)_{1999}-\ln (Y / L)_{1969}$.

\begin{tabular}{|c|c|c|c|c|c|c|}
\hline \multirow[b]{3}{*}{ Parameters } & \multicolumn{5}{|c|}{ CES Model $(\rho \neq 0)$} & \\
\hline & \multicolumn{2}{|c|}{ All LMAs } & \multicolumn{2}{|c|}{ Metropolitan LMAs } & \multicolumn{2}{|c|}{ Nonmetropolitan LMAs } \\
\hline & Coefficient & $\overline{\text { Std Error }}$ & Coefficient & $\overline{\text { Std Error }}$ & $\overline{\text { Coefficient }}$ & Std Error \\
\hline$\pi$ & $0.98951^{* *}$ & 0.00077 & $0.99230^{* *}$ & 0.00113 & $0.98454^{* *}$ & 0.00106 \\
\hline$A(0)$ & $30.4517^{* *}$ & 4.01269 & $65.2636^{* *}$ & 19.75361 & $21.3159^{* *}$ & 2.33444 \\
\hline a & $0.07959^{* *}$ & 0.03890 & -0.02009 & 0.01839 & $0.08556^{* *}$ & 0.03019 \\
\hline$\beta$ & $0.17296^{* *}$ & 0.06252 & $0.28118^{*}$ & 0.14673 & $0.12076^{* *}$ & 0.04513 \\
\hline$\gamma$ & $-0.23800^{* *}$ & 0.09304 & -0.03933 & 0.04316 & -0.06849 & 0.05859 \\
\hline$\rho$ & 0.01008 & 0.18346 & -3.54385 & 3.64081 & 0.12599 & 0.09503 \\
\hline Adj $R^{2}$ & 0.257 & & 0.194 & & 0.376 & \\
\hline Obs. & 722 & & 256 & & 466 & \\
\hline \multicolumn{7}{|c|}{ CD Model $(\rho=0)$} \\
\hline$\pi$ & $0.98951^{* *}$ & 0.00077 & $0.99256^{* *}$ & 0.00069 & $0.98456^{* *}$ & 0.00084 \\
\hline$A(0)$ & $30.4320^{* *}$ & 3.93243 & $46.4262^{* *}$ & 8.23513 & $20.9104^{\star *}$ & 1.73027 \\
\hline a & $0.07782^{* *}$ & 0.03408 & $-0.15938^{* *}$ & 0.05365 & $0.06357^{* *}$ & 0.02275 \\
\hline$\beta$ & $0.17348^{\star *}$ & 0.06253 & $0.55123^{* *}$ & 0.09593 & $0.13084^{* *}$ & 0.03712 \\
\hline$r$ & $-0.23653^{* *}$ & 0.07562 & $-0.43057^{* *}$ & 0.11622 & $-0.06932^{*}$ & 0.03892 \\
\hline Adj $R^{2}$ & 0.258 & & 0.186 & & 0.375 & \\
\hline Obs. & 722 & & 256 & & 466 & \\
\hline
\end{tabular}

Note: A single asterisk $\left(^{*}\right)$ denotes statistically significant at $10 \%$ level. Double asterisks $\left(^{* *}\right)$ denote statistically significant at $5 \%$ level. Regression results are computed from restricted estimation using nonlinear two stage least squares. Standard errors are corrected to ensure consistency.

Shleifer (1995). The estimate of the elasticity of substitution $(\rho)$ is positive but not significantly different from zero at the $10 \%$ level.

A key consideration in this article is the validity of pooling the metropolitan and nonmetropolitan data. We test this hypothesis and find that pooling of the data for metropolitan and nonmetropolitan labor market areas is rejected (at the 1\% level). We also find significant (at the 5\% level or better) differences for all individual parameters. As a result, we provide separate results for metropolitan and nonmetropolitan LMAs in Table 3.

We find interesting differences in the impact of investment rates on growth across metropolitan and nonmetropolitan areas, as Table 3 shows. Private capital investment in manufacturing has a positive and significant impact on per capita personal income growth in nonmetropolitan areas, but a negative (although not significant) impact on growth in metropolitan areas. For metropolitan areas, this is similar to results obtained by Crihfield and Panggabean (1995), who found a negative but insignificant correlation between manufacturing investment and income growth during the 1960-77 period. This is also consistent with results reported in Glaeser, Scheinkman, and Shleifer
(1995), who find a strong negative correlation between the manufacturing employment share in 1960 and growth during the 1960-90 period for SMSAs in their sample. It also reflects the relative employment trends across metropolitan and nonmetropolitan areas. Using employment data from the U.S. Bureau of Economic Analysis, the manufacturing share of jobs in metropolitan areas has fallen from 23\% in 1969 to $11 \%$ by 1999 . The share relative decline has been less severe in nonmetropolitan areas, falling from 20.6\% in 1969 to $15.7 \%$ by $1999 .{ }^{5}$

While we find that public capital investment had a significant negative impact on growth for the full sample of LMAs, we find that the coefficient on public capital investment is negative but insignificant after disaggregating across metropolitan and nonmetropolitan areas. For metropolitan areas, these results are similar to Crihfield and Panggabean (1995), Dalenberg and Partridge (1995), and Glaeser, Scheinkman, and Shleifer (1995) and for nonmetropolitan areas the results are consistent with evidence reported by Chandra and Thompson (2000) for highways. Overall,

\footnotetext{
${ }^{5}$ Manufacturing employment defined using the Standard Industrial Classification.
} 
this suggests that infrastructure development at the margin did not contribute significantly to growth in U.S. substate areas during the 1969-99 period.

A consistent result across metropolitan and nonmetropolitan areas is the positive and significant coefficient on human capital investment, which highlights again the importance of education in growth. There are, however, significant differences in the impact of education. To examine this, we compute a simulation of the effects of human capital investment on growth using our restricted CES results. We examine the impact of a $10 \%$ increase in human capital investment in both metropolitan and nonmetropolitan labor market areas. Such an increase leads to a 0.032 percentage point (or $1.92 \%$ ) increase in annual per capita income growth in metropolitan areas, and a 0.021 percentage point (or 1.32\%) increase in annual per capita income growth in nonmetropolitan areas. The contribution of human capital investment to income growth is approximately $50 \%$ greater in metropolitan areas than in nonmetropolitan areas.

The greater impact of human capital investment in metropolitan than nonmetropolitan areas is consistent with Hammond and Thompson (2006), Hammond (2006), Henry, Barkley, and Li (2004), and Huang, Orazem, and Wohlgemuth (2002). Our research shows that education has a significant positive impact on income growth in nonmetropolitan areas, using an exhaustive set of labor markets for the continental United States and controlling for endogeneity.

With respect to the elasticity of substitution, our results are mixed. In an unrestricted regression, Ftests on the joint significance of the CES coefficients (squared terms in brackets in equation (1)) reject the null hypothesis in the case of nonmetropolitan areas. However, the estimated value of $\rho$ from our restricted regressions is not significantly different from zero for either metropolitan or nonmetropolitan areas. This suggests that the $C D$ specification may be valid and we include results from restricted regressions imposing $\rho=0$. The results are broadly similar to the CES regressions, although the coefficients on investment rates are larger in the metropolitan estimation.

Finally, with respect to the coefficient on initial income, which is commonly referred to in the literature as the conditional convergence coefficient, Quah (1993) has forcefully argued that it must be interpreted carefully. In particular, Quah (1993) shows that a significant negative coefficient on initial income in a cross-section growth regression does not imply that income levels are becoming more similar during the estimation period. We do not place the convergence interpretation on the coefficient of initial income. Rather, we view it as indicating that initially lowerincome areas have tended to grow faster than initially higher-income areas, after accounting for steady-state determinants, which is what we observe. ${ }^{6}$

\section{Conclusions}

Our results show significant differences in the determinants of growth between metropolitan and nonmetropolitan labor market areas, which result from structural differences across labor markets. This important result implies that policy makers should take metropolitan/nonmetropolitan differences into account when designing policies to enhance economic development.

One common theme across metropolitan and nonmetropolitan areas is the importance of human capital for growth. This suggests that state and local economic development officials should focus their efforts on encouraging education and retaining and attracting better-educated residents. However, we find that human capital investment has a stronger impact on income growth in metropolitan areas than in nonmetropolitan areas.

In contrast to the large positive impact of human capital investment on growth, we find little correlation between public capital outlays and income growth. This mirrors the results reported in the literature for both metropolitan and nonmetropolitan areas and suggests that this type of investment should not be targeted by state and local officials in order to spur economic development.

Finally, we find that private physical capital investment in the manufacturing sector encourages per capita income growth in nonmetropolitan areas but not in metropolitan areas. This likely reflects the relative decline in manufacturing in metropolitan areas during the period and the resiliency of manufacturing activity in nonmetropolitan areas.

\footnotetext{
${ }^{6}$ See Hammond and Thompson (2006), Hammond (2006), and Hammond (2004) for analyses of convergence in this dataset using valid empirical techniques. Under the convergence interpretation, our results from Table 3 suggest that all regions converge to their steady states at a rate of $1.1 \%$ per year. This is similar to the speed of convergence across U.S. states reported by Barro and Sala-i-Martin (1999), at $0.9 \%$. Our results suggest a somewhat slower rate of convergence for all metropolitan areas $(0.8 \%$ per year) than we do for nonmetropolitan regions $(1.5 \%$ per year).
} 
Our results emphasize the impact of structural differences across metropolitan and nonmetropolitan areas, particularly the large difference in the boost provided by human capital investment. This heterogeneity may arise from differences in industry and occupational structure across metropolitan and nonmetropolitan areas, as metropolitan areas have captured much of the growth in human-capital-intensive service sector employment. This development is related to the importance of agglomeration economies in driving growth in knowledge-based sectors, which is a development path that small nonmetropolitan economies will have trouble replicating. Further, nonmetropolitan reliance on extractive and manufacturing sectors increases their exposure to intense international competitive pressures, which may adversely impact the distribution of income. As Leatherman and Marcouiller (1999) point out, the evolution of income inequality is an important frontier for future research.

Our results do not necessarily imply that nonmetropolitan economies will be trapped in low growth modes. Economic development efforts aimed at preserving and capitalizing on natural amenities and other quality-of-life factors are likely to be important factors driving nonmetropolitan growth in the future, particularly to the extent that they are combined with efforts to expand entrepreneurial incentives.

\section{References}

Allen, R.G.D. 1938. Mathematical Analysis for Economists. London: Macmillan.

Barro, R.J., X. Sala-i-Martin. 1992. “Convergence.” Journal of Political Economy 100:223-51.

Barro, R.J., X. Sala-i-Martin. 1999. Economic Growth. Cambridge: The MIT Press.

Baumol, W.J. 1986. "Productivity Growth, Convergence, and Welfare: What the Long-Run Data Show." American Economic Review 76:1072-85.

Beeson, P., D. DeJong, W. Troesken. 2001. "Population Growth in U.S. Counties 1840-1990." Regional Science and Urban Economics 31:669-99.

Carlino G., L. Mills. 1993. “Are U.S. Regional Incomes Converging? A Time Series Analysis." Journal of Monetary Economics 32:335-46.

Carlino G., L. Mills. 1987. "The Determinants of County Growth." Journal of Regional Science 27:39-54.
Carlino G., L. Mills. 1996. "Convergence and the U.S. States: A Time Series Analysis." Journal of Regional Science 36:597-616.

Chandra, A., E. Thompson. 2000. "Does Public Infrastructure Affect Economic Activity? Evidence from the Rural Interstate Highway System." Regional Science and Urban Economics 30:457-90.

Crihfield, J.B., M.P.H. Panggabean. 1995. "Growth and Convergence in U.S. Cities." Journal of Urban Economics 38:138-65.

Dalenberg, D.R., M.D. Partridge. 1995. “The Effects of Taxes, Expenditures, and Public Infrastructure on Metropolitan Area Employment." Journal of Regional Science 35:617-40.

Deller, S.C., M. Shields, D. Tomberlin. 1996. “Price Differentials and Trends in State Income Levels: A Research Note." Review of Regional Studies 26:99-113.

Deller, S.C., T.H. Tsai, D.W. Marcouiller, D.B.K. English. 2001. "The Role of Amenities and Quality of Life in Rural Economic Growth." American Journal of Agricultural Economics 83:352-65.

DeLong, J.B. 1988. "Productivity Growth, Convergence, and Welfare: Comment," American Economic Review 78:1138-54.

Drennan, M.P. 2005. “Possible Sources of Wage Divergence among Metropolitan Areas of the United States." Urban Studies 42:1609-20.

Duffy, J., C. Papageorgiou. 2000. “A Cross-Country Empirical Investigation of the Aggregate Production Function Specification." Journal of Economic Growth 5:87-120.

Glaeser, E.L., A. Saiz. 2004. "The Rise of the Skilled City." Brookings-Wharton Papers on Urban Affairs, 47-94.

Glaeser, E.L., J.A. Scheinkman, A. Shleifer. 1995. “Economic Growth in a Cross-Section of Cities." Journal of Monetary Economics 36:117-143.

Hammond, G.W. 2006. "A Time Series Analysis of U.S. Metropolitan and Non-metropolitan Income Divergence." Annals of Regional Science 40:81-94.

Hammond, G.W.. 2004. "Metropolitan/Non-metropolitan Divergence: A Spatial Markov Chain Approach." Papers in Regional Science 83:543-63.

Hammond, G.W., E.C. Thompson. 2008. “AJAE Appendix: Determinants of Income Growth in Metropolitan and Non-metropolitan Labor Markets." Unpublished manuscript. Available at: http://0-agecon.lib.umn.edu.library.unl.edu:80/.

Hammond, G.W., E.C. Thompson. 2006. “Convergence and Mobility: Personal Income Trends in U.S. Metropolitan and Non-metropolitan Region." International Regional Science Review 29:35-63.

Henry, M.S., D. Barkley, H. Li. 2004. "Education and Nonmetropolitan Income Growth in the South." Review of Regional Studies 34:223-44. 
Huang, T.L., P.F. Orazem, D. Wohlgemuth. 2002. “Rural Population Growth, 1950-1990: The Roles of Human Capital, Industry Structure, and Government Policy." American Journal of Agricultural Economics 84:615-27.

Kim, K.K., D.W. Marcouiller, S.C. Deller. 2005 “Natural Amenities and Rural Development: Understanding Spatial and Distributional Attributes." Growth and Change 36:273-97.

Klump, R., H. Preissler. 2000. "CES Production Functions and Economic Growth." Scandanavian Journal of Economics 102:41-56.

Leatherman, J.C., D.W. Marcouiller. 1999. “Moving Beyond the Modeling of Regional Economic Growth: A Study of How Income Is Distributed to Rural Households." Economic Development Quarterly 13:38-45.

Lucas, R.E. 1988. "On the Mechanics of Economic Development." Journal of Monetary Economics 22:3-42.

Masanjala, W.H., C. Papageorgiou. 2004. "The Solow Model with CES Technology: Nonlinearities and Parameter Heterogeneity." Journal of Applied Econometrics 19:171-201.

McGranahan, D.A. 1999. "Natural Amenities Drive Rural Population Change," Agricultural Economic Report \#781, USDA Economic Research Service, Food and Rural Economics Division.

Nissan, E., G. Carter. 1999. “Spatial and Temporal Metropolitan and Nonmetropolitan Trends in Income Inequality." Growth and Change 30:407-29.
Quah, D. 1996. "Aggregate and Regional Disaggregate Fluctuations." Empirical Economics 21:137-59.

Quah, D.. 1993. "Galton's Fallacy and Tests of the Convergence Hypothesis." Scandinavian Journal of Economics 95:427-43.

Rauch, J.E. 1993. "Productivity Gains from Geographic Concentration of Human Capital: Evidence from the Cities." Journal of Urban Economics 34:380-400.

Rupasingha, A., S.J. Goetz, David Freshwater. 2002. “Social and Institutional Factors as Determinants of Economic Growth: Evidence from the United States Counties." Papers in Regional Science 81:139-55.

Simon, C.J. 1998. "Human Capital and Metropolitan Employment Growth." Journal of Urban Economics 43:223-43.

Simon, C.J C. Nardinelli. 2002. "Human Capital and the Rise of American Cities, 1900-1990." Regional Science and Urban Economics 32:59-96.

Solow, R. 1956. "A Contribution to the Theory of Economic Growth." Quarterly Journal of Economics 70:65-94.

Tolbert, C.M., M. Sizer. 1996. “U.S. Commuting Zones and Labor Market Areas: A 1990 Update," ERS Staff Paper \# 9614, USDA Economic Research Service, Rural Economy Division.

White, H. 1980. "A Heteroskedasticity-Consistent Covariance Matrix and a Direct Test for Heteroskedasticity." Econometrica 48:817-38. 